\title{
CERITA PROSA RAKYAT DI SURAU TUANKU MUDIAK TAMPANG: DOKUMENTASI DAN KLASIFIKASI
}

\author{
Rafika Duri $^{1^{*}}$, Eka Meigalia ${ }^{2}$, Pramono ${ }^{3}$ \\ rafikaduri@gmail.com* \\ Fakultas Ilmu Budaya Universitas Andalas ${ }^{1,2,3}$
}

\begin{abstract}
ABSTRAK
Artikel ini mendeskripsikan klasifikasi hasil dokumentasi cerita prosa rakyat yang ada di sekitar Surau Tuanku Mudiak Tampang, Rao, Kabupaten Pasaman. Teknik pengumpulan data dilakukan dengan studi lapangan dengan langkahlangkah observasi, wawancara, pencatatan, transkipsi, klasifikasi, serta analisis cerita. Hasilnya, ditemukan dua puluh tiga cerita prosa rakyat di sekitar Surau Tuanku Mudik Tampang, Rao, Kabupaten Pasaman. Setelah didokumentasikan dan dilakukan pengklasifikasian semua cerita prosa rakyat dikelompokkan ke dalam legenda, lima cerita jenis legenda setempat, satu cerita legenda alam gaib, tujuh cerita legenda perseorangan, dan sepuluh cerita legenda keagamaan.
\end{abstract}

Kata-kata kunci: Cerita Prosa Rakyat, Folklor, Mudiak Tampang, Rao

\section{THE FOLK STORY AROUND SURAU TUANKU MUDIAK TAMPANG: DOCUMENTATION AND CLASSIFICATION}

\begin{abstract}
This article describes folk prose stories around Surau Tuanku Mudiak Tampang, Rao, Pasaman Regency. The data collection technique was carried out by field studies with observation, interviews, recording, transcription, classification, and story analysis. As a result, twenty-three folk prose stories were found around Surau Tuanku Mudik Tampang, Rao, Pasaman Regency. After being documented and classified, all folk prose stories were grouped into legends, five types of local legends, one legend of the occult, seven individual legends, and ten religious legends.
\end{abstract}

Keywords: Folk Stories, Folklore, Mudiak Tampang, Rao

Jurnal Elektronik WACANA ETNIK - Vol 9 No 2, 2020, (102 - 115) p ISSN 2089-8746, e ISSN 2302-7142

Submit: Agustus 2020. Diterima: September 2020. Publikasi: Oktober 2020. 


\section{PENGANTAR}

Bagi masyarakat Minangkabau, surau tidak hanya berfungsi sebagai tempat beribadah. Surau juga dijadikan tempat kegiatan bagi anak laki-laki yang sudah akil balig, pendidikan terutama untuk belajar mengaji, belajar salat, belajar ilmu tarekat, serta belajar ilmu bela diri (silat). Banyak surau di Minangkabau yangmenjadi tempat belajar agama dan tarekat. Salah satu tarekat yang berkembang ialah Tarekat Naqsyabandiyah. Tarekat Naqsyabandiyah banyak terdapat di surau-surau di Minangkabau, seperti Surau Batu Hampar di Lima Puluh Kota, Surau Cangkiang dan Surau Pasir di Agam, Surau Baru di Padang, Surau Silungkang, Surau Kasik di Singkarak, Surau Tuanku Mudik Tampang di Rao dan surau lainnya (Azra, 2003: 63-64).

Satu surau Tarekat Naqsyabandiyah yang belum begitu dikenal khalayak luas ialah Surau Tuanku Mudik Tampang. Surau ini terletak di jorong I Mudik Tampang, Kanagarian Tarung-Tarung, Kecamatan Rao, Kabupaten Pasaman.Lokasi surau berjarak kurang lebih 223,9 km2 dari Kota Padang. Menariknya, surau ini merupakan salahsatu pusat pendidikan Islam tertua di Rao yang dipimpin oleh ulama besar yang bergelar Tongku. Surau Mudik Tampang telah memainkan peran penting dalam penyebaran Islam di Rao. Surau tersebut menjadi pusat Tarekat Naqsyabandiyah terbesar di Rao. Jamaah tarekat tersebut tidak hanya masyarakat Rao, namun juga berasal dari berbagai daerah di luar tanah Rao. Di surau yang berumur 330 tahun ini, juga terdapat naskah-naskah kuno yang bernuansa Islami. Selain itu, di surau dan wilayah sekitarnya juga dikenal cerita prosa rakyat yang dianggap benarbenar pernah terjadi.

Cerita prosa rakyat sekitar Surau Tuanku Mudik Tampang belum begitu diketahui dan dikenal. Sebenarnya banyak cerita prosa rakyat, namun hanya sedikit yang diceritakan (diwariskan). Sementara, yang lainnya masih ada dalam ingatan beberapa masyarakat yang usianya pun sudah lanjut. Cerita prosa rakyat mengandung nilai-nilai budaya, sejarah, pendidikan, dan lainnya. Cerita prosa rakyat tersebut akan didokumentasi dan diklasifikasikan. Dengan meneliti cerita prosa rakyat di sekitar Surau Tuanku Mudik Tampang, menunjukkan bagaimana kehidupan, sejarah, budaya, pendidikan di masa lalu.Maka penelitian ini perlu dilakukan sebagai bentuk pendokumentasian cerita prosa rakyat yang berkembang di masyarakat.

\section{KERANGKA TEORI DAN METODE}

Menurut Alan Dundes (dalam Dananjaja, 2002: 1-2) secara etimologis folkadalah sekelompok orang yang memiliki ciri-ciri pengenal fisik, sosial dan kebudayaan, sehingga dapat dibedakan dari kelompok-kelompok lainnya. Sementara itu, lore adalah tradisi dari folk, yaitu sebagian dari kebudayaan yang diwariskan secara turun temurun secara lisan atau melalui suatu contoh yang disertai dengan gerak isyarat atau alat pembantu pengingat. Jadi folklor adalah sebagian kebudayaan suatu kolektif, yang tersebar dan diwariskan turun temurun, diantara kolektif macam apa saja.

Brunvand (dalam Dananjaja, 2002: 21-22) mengatakan bahwa folklor dapat dikelompokkan ke dalam tiga golongan, yaitu folklor lisan, folklor sebagian lisan, dan folklor bukan lisan. Menurut Bascom (dalam Dananjaja, 2002: 19) fungsi folklor terutama folklor lisan dan sebagian lisan masih menarik dan penting untuk oleh ahli-ahli ilmu

Jurnal Elektronik WACANA ETNIK - Vol 9 No 2, 2020, (102 - 115) p ISSN 2089-8746, e ISSN 2302-7142 
masyarakat dan psikologi dalam rangka melaksanakan pembangunan bangsa. Fungsi-fungsi yang dimaksud yaitu (1) sebagai sistem proyeksi (projective system) yakni sebagai alat pencermin agan-agan suatu kolektif; (2) sebagai alat pengesahan pranata-pranata dan lembaga-lembaga kebudayaan; (3) sebagai alat pendidikan anak (pedadogical device); dan (4) sebagai alat pemaksa dan pengawas agar norma-norma masyarakat akan selalu dipatuhi anggota kolektifnya.

William R. Bascom (dalam Dananjaja, 2002: 50) membagi cerita prosa rakyat menjadi tiga golongan, yaitu (1) mite (myth) adalah cerita prosa rakyat yang dianggap benar terjadi dan dianggap suci oleh yang memiliki cerita tersebut. Mite ditokohi oleh dewa ataupun makhluk setengah dewa dan tempat terjadinya cerita di dunia lain bukan di dunia yang di tempati oleh manusia (bumi); (2) legenda (legend) adalah cerita prosa rakyat yang dianggap benar-benar terjadi dan terjadinya pada masa lampau serta bertempat di dunia yang di tinggali oleh manusia (bumi). Legenda dikelompokkan menjadi 4 bagian yaitu: (a) legenda setempat (local legends), yaitu legenda yang berhubungan dengan cerita suatu tempat, nama tempat, bentuk topografi dan bentuk permukaan suatu daerah. (b) legenda alam gaib (supranatural legends), yaitu legenda yang menceritakan tentang suatu kisah yang dianggap pernah benar-benar terjadi serta pernah dialami oleh seseorang. (c) legenda perseorangan (personal legends), yaitu legenda yang bercerita tentang tokoh-tokoh tertentu, yang dianggap oleh pemilik cerita tersebut pernah benar-benar terjadi. (d) legenda keagamaan (religious legends), legenda yang menceritakan tentang orang-orang suci (sainst) Nasrani. Legenda seperti ini telah diakui dan disahkan oleh gereja katolik Roma akan menjadi dari kesusastraan agama yang berarti tulisan, karangan, atau buku mengenai kehidupan orang-orang saleh; dan (3) dongeng (folktale) adalah cerita prosa rakyat yang dianggap tidak benar-benar terjadi.

Peneliti meninjau secara langsung ke tempat penelitian atau observasi lapangan terhadap objek yang akan diteliti. Observasi ini dilakukan guna meninjau langsung lokasi tempat penelitian supaya memperoleh data yang dibutuhkan, serta mengumpulkan data mengenai objek penelitian, lokasi penelitian, dan pemilihan informan. Pemilihan informan dilakukan agar data yang diperoleh jelas dan tidak dibuat-buat. Informan yang telah dijaring peneliti yaitu: 'Tongku' (Syekh) Surau Tuanku Mudik Tampang, orang tua-tua yang berusia di atas 55 tahun, serta masyrakat sekitar Surau Tuanku Mudik Tampang yang mengetahui mengenai objek.Untuk memperoleh data yang diinginkan, peneliti melakukan pengamatan, pencatatan, pengumpulan, dan perekaman data yang akan digunakan dalam penelitian.

Untuk mendapatkan data yang diinginkan peneliti melakukan upaya pengamatan dan pengenalan lebih dekat terhadap masyarakat di Mudik Tampang. Langkah ini penting, karena usaha ini dapat menjalin hubungan yang harmonis antara peneliti dengan masyarakat Mudik Tampang. Selanjutnya peneliti mulai mewawancarai informan yang telah dipilih sebelumnya.Informan yang peneliti wawancarai adalah: a. TongkuSurau Tuanku Mudik Tampang, b. Informan yang berusia di atas 55 tahun, serta masyarakat sekitar Surau Tuanku Mudik Tampang yang tinggal menetap minimal tiga puluh tahun secara berturut-turut di Mudik Tampang, dan c. Informan warga asli, bukan pendatang. Setelah menentukan para informan, peneliti mulai melakukan wawancara dengan informan. Peneliti menemui para informan di Surau Tuanku Mudik Tampang dan di rumah informan, menanyai cerita-cerita yang berkembang di sekitar surau serta peninggalan-peninggalan Syekh Mudik Tampang dahulunya.

Jurnal Elektronik WACANA ETNIK - Vol 9 No 2, 2020, (102 - 115) p ISSN 2089-8746, e ISSN 2302-7142 
Teknik wawancara yang digunakan adalah wawancara tidak terstruktur (bebas). Artinya wawancara dilakukan tanpa terikat oleh susunan daftar pertanyaan yang dibuat oleh peneliti.Pertanyaan-pertanyaan muncul secara spontan mengikuti alur pembicaraan yang telah diarahkah oleh peneliti.Pada waktu yang bersamaan peneliti merekamwawancara dengan informan agar data yang diperoleh pada saat penelitian tidak hilang atau berubah-ubah. Peneliti juga menggunakan alat tulis untuk mencatat hal-hal yang dirasa penting dan merekam meggunakan alat rekam.

Hasil pengamatan dan wawancara dituangkan dalam bentuk tulisan. Sebelum diarsipkan, terlebih dahulu harus ditranskripsi ke dalam bahasa Indonesia. Hasil pengamatan dan wawancara disalin dengan lengkap. Pada arsip data, perlu ditulis nama, umur, pekerjaan, dan latar belakang lain yang mendukung. Hal ini akan memudahkan analisis data. Koleksi data tersebut, sekurang-kurangnya harus memuat empat hal yaitu: (a) pengambil data, (b) teks bentuk sastra lisan, (c) konteks bentuk sastra lisan yang berasal dari informan, (d) komentar dan penilaian informan terhadap data yang telah terkumpul.

\section{HASIL DAN PEMBAHASAN}

Jika dilihat dari isi cerita, terlihat bahwa cerita prosa rakyat di sekitar Surau Tuanku Mudik Tampang ini dapat diklasifikasikan ke jenis legenda. Dari hasil penelitian tersebut diperoleh dua puluh tiga cerita prosa rakyat. Semua jenis cerita prosa rakyat sekitar Surau Tuanku Mudik Tampang diklasifikasikan ke dalam legenda. Legenda adalah cerita prosa rakyat yang dianggap oleh yang empunya cerita sebagai suatu kejadian yang pernah terjadi dan mempunyai ciri yang mirip dengan mite, tetapi tidak dianggap suci. Legenda ditokohi oleh manusia walaupun kadang manusia memiliki sifat yang luar biasa dan juga dibantu oleh makhluk gaib, cerita terjadi di dunia seperti yang kita kenal karena waktu terjadinya tidak terlalu lama

\section{Legenda Setempat}

Cerita tentang asal nama Surau Tuanku Mudik Tampang ini penulis golongkan ke dalam jenis legenda setempat (local legends), hal ini berdasarkan pada kenyataan bahwa terdapat hubungan yang kuat antara cerita ini dengan nama suatu tempat. Cerita ini menceritakan tentang asal nama Surau yang ada di Mudik Tampang. Pada umumnya masyarakat yang berada di Mudik Tampang percaya akan kebenaran cerita asal nama Surau Tuanku Mudik Tampang. Hal ini dikarenakan adanya bukti-bukti yang erat kaitan dengan cerita. Asal mula nama Surau Tuanku Mudik Tampang berangkat dari gelar ulama Islam di Minangkabau, yaitu gelar Tuanku. Gelar Tuanku diberikan kepada syekh Mudik Tampang yang mengajarkan agama Islam, mengislamkan orang-orang di Tanah Rao dan luar daerah Rao. Gelar tersebut diwariskan kepada anak kemenakannya.

Sesuai dengan yang telah diceritakan dalam teks cerita, asal nama Surau Tuanku Mudik Tampang ini berangkat dari gelar pemimpin surau dan nama daerah terdapatnya surau. Pada saat sekarang ini dapat kita lihat surau yang ada di Mudik Tampang yang di pimpin oleh seseorang yang bergelar Tuanku. Surau ini menjadi saksi bisu peninggalan budaya di masa lalu. Mudik Tampang dari dahulunya sampai sekarang menjadi pusat pengajaran agama Islam terbesar di Tanah Rao. Sekarang ini surau dijadikan sebagai tempat bersuluk bagi jamaah laki-laki. Bukti lain

Jurnal Elektronik WACANA ETNIK - Vol 9 No 2, 2020, (102 - 115) p ISSN 2089-8746, e ISSN 2302-7142 
yang membuat masyarakat percaya dengan kebenaran cerita ini adalah terdapatnya kondisi geografis surau maksudnya, di dekat surau banyak terdapat areal persawahan, dan perkebunan.

Tuanku sampai saat sekarang ini masih menjadi pemimpin di Surau Tuanku Mudik Tampang. Sekarang Tuanku menjadi guru spiritual bagi jamaah suluk tarekat Naqsabandiyah yang beliau pimpin. Tuanku juga menjadi penerus kepemimpinan sebuah pesantren yang ada di dekat surau. Gelar Tuanku mulai dari Muhammad Ali (Tuanku Mudik Tampang I), Muhammad Nur (Tuanku Mudik Tampang II), Makruf (Tuanku Mudik Tampang III), Khalid (Tuanku Mudik Tampang VI), Zainuddin (Tuanku Mudik Tampang V), Muhammad Yahya (Tuanku Mudik Tampang VI), Muhammad Zein (Tuanku Mudik Tampang VI dan VII), Ahmad Effendi (Tuanku Mudik Tampang VII), Ahmad Khalidi Sanusi (Tuanku Mudik Tampang VIII). Dengan melihat silsilah keturunan gelar Tuanku ini membuat seluruh masyarakat Mudik Tampang percaya akan kebenaran cerita yang di klasifikasikan ke dalam legenda setempat (local legends).

Salah satu contoh kebenaran cerita yaitu, kata Mudik Tampang yang sekarang ini. Menurut cerita dahulunya Madok Mudiak Tampang dari kata madok 'menghadap' dan tampang 'wajah' memiliki arti mengarahkan wajah, sedangkan kata mudiak 'asa', sumber' artinya sumber air bersih untuk berwudu, jadi arti dari kata Mudik Tampang adalah mengambil wudu untuk melaksanakan salat. Sampai saat sekarang ini kata Mudik Tampang masih tetap dipakai. Istilah madok tidak lagi digunakan oleh masyarakat setempat dalam menjalankan kehidupan sehari-hari, meskipun kata madok tidak lagi digunakan, tetapi masyarakat Mudik Tampang masih mengakui bahwa bahasa itu adalah milik kelompok masyarakatnya. Hal ini dapat menjadi salah satu bukti bahwa adanya hubungan kuat antara cerita dengan kenyataan yang ada. Mudik Tampang dari dahulu sampai sekarang kaya akan sumber daya alam air bersihnya. Mudik Tampang menjadi pusat pengajaran agama Islam di tanah Rao. Hal itu dapat dilihat dengan banyaknya masyarakat luar datang ke Mudik Tampang untuk belajar agama.

Cerita tentang asal usul Mudik Tampang berawal dari keringnya sungai tempat biasa masyarakat Mudik mengambil air. Masyarakat memanfaatkan sumber air untuk kebutuhan hidup sehari-hari. Sesuai dengan yang telah diceritakan dalam teks cerita, mulanya nama daerah itu hanya Mudik, karena adanya perjuangan masyarakat berjalan kaki berkilo-kilo meter mencari penyebab kekeringan, yang disebabkan oleh pohon besar yang tumbang sehingga membuat air tidak mengalir ke Mudik, maka masyarakat sepakat menamai daerahnya menjadi Mudik Tumbang. Lama kelamaan kata Mudik Tumbang berubah menjadi kata Mudik Tampang. Masyarakat Mudik Tampang pada umumnya percaya akan cerita tersebut. Sampai saat sekarang ini pun masih banyak terdapat pohon-pohon besar di tepi sungai. Apabila salah satu pohon tumbang air tidak akan mengalir ke sungai, air meluap ke sawah atau parit.

Cerita tentang asal usul Mudik Tampang juga menceritakan nenek moyang orang Mudik Tampang yang gemar bercocok tanam. Semua jenis tanaman untuk kebutuhan hidup sehari hari ada di sini. Tanaman tubuh subur karena dekat dengan sumber air. Banyak masyarakat luar daerah Mudik Tampang yang membeli hasil panen nenek moyang orang Mudik Tampang, sehingga orang-orang sepakat menamai kampung Mudik Tampang.

Cerita tentang asal usul Mudik Tampang juga bercerita tentang dahulu Kampung Mudik Tampang ini hanya bernama kampung Mudik saja. Karena wilayah kampung Mudik yang sempit dan jumlah penduduk setiap tahunnya meningkat, maka dibersihkan semak belukar yang ada di atas kampung Mudik sehingga menjadi perkampungan.

Jurnal Elektronik WACANA ETNIK - Vol 9 No 2, 2020, (102 - 115) p ISSN 2089-8746, e ISSN 2302-7142 
Orang-orang yang tinggal di sana masih asli keturunan orang Mudik maka jadilah Mudik Tampang. Tampang dapat diartikan sebagai bibit, dalam silsilah keluarga ialah keturunan. Masyarakat Mudik Tampang percaya dengan cerita ini, karena sampai saat sekarang ini pun yang menjadi penduduk Mudik Tampang memang asli orang Mudik Tampang. Pada saat sekarang ini wilayah Mudik Tampang semakin luas, meskipun begitu lahan untuk dijadikan perumahan masih tersedia.

Pada umumnya masyarakat yang berada di Mudik Tampang percaya akan kebenaran cerita asal usul Mudik Tampang ini. Hal ini dapat dilihat dari bukti-bukti yang telah dipaparkan di atas. Pada saat sekarang pun masih banyak keturunan orang Mudik Tampang yang membuat rumah di Tampang. Hal tersebut berkaitan erat dengan kenyataan cerita di masa dahulunya. masyarakat menebang pohon-pohon besar dan membersihkan semak belukar untuk di jadikan lokasi membuat rumah.

Oleh karena itu akhirnya masyarakat percaya kalau cerita tersebut memang pernah terjadi pada dahulu kalanya, bahkan sampai sekarang pun masih banyak yang hendak membuat rumah di Mudik Tampang. Meskipun wilayah Mudik Tampang luas, subur, dekat dengan sumber air namun tidak ada pendatang yang mencoba membuat rumah di sana. Orang-orang sadar, bahwa Mudik Tampang ini hanya untuk anak cucu keturunan Mudik Tampang saja. Jika ada pendatang yang membuat rumah di Mudik Tampang pasti terlebih dahulu meminta izin ke ninik mamak, penghulu, bapak jorong, dan lainnya sehingga pendatang dapat dengan mudah bersosialisasi dengan keturunan Mudik Tampang.

\section{Legenda Alam Gaib}

Legenda alam gaib Penampakan Dosa merupakan legenda yang berasal dari Mudik Tampang. Legenda ini penulis golongkan pada jenis legenda alam gaib (supranatural legends) karena cerita ini dianggap oleh masyarakat setempat pernah benar-benar terjadi dan pernah dialami seseorang. Pengklasifikasian ini berdasarkan atas beberapa informan serta keterangan dari masyarakat setempat dan luar daerah Mudik Tampang mengatakan juga pernah melihat penampakan dosa-dosa yang telah dilakukan. Penampakan dosa ini dapat dilihat ketika sedang melaksanakan ibadah suluk di dalam kelambu. Di dalam kelambu hanya ada kita dan amalan selama kita hidup di dunia. Apa pun yang dilihat ketika beribadah suluk, itulah gambaran dosa-dosa yang telah dilakukan.

Setiap amalan baik dan buruk yang telah dilakukan akan terlihat di saat suluk. Salah-satu jemaah suluk tarekat Naqsyabandiyah dapat melihat dosa-dosanya berwujud orang yang sangat besar, hitam, membawa parang menemuinya. Beberapa informan juga mengakui pernah mengikuti ibadah suluk dan juga melihat penampakan dosadosa yang telah dilakukannya. Pada umumnya informan melihat penampakan yang buruk-buruk dari amalannya. Jarang sekali ada yang melihat yang baik-baik dari amalannya. Hal ini di percaya masyarakat Mudik Tampang karena amalan buruk yang dilakukan manusia dapat menyadarkan siapa pun untuk bertobat dan lebih dekat lagi pada sang pencipta. Di dalam suluk, ibaratkan manusia berada di dalam kuburan karena semua amalan baik dan buruk akan terlihat di sana. Cerita tentang Penampakan Dosa ini sangat dipercaya oleh masyarakat Mudik Tampang.

Ibadah suluk merupakan salah satu jalan untuk mendekatkan diri kepada Allah SWT. Banyak masyarakat yang masih melaksanakan ibadah suluk, baik orang asli Mudik Tampang maupun luar daerah. Ibadah suluk di Mudik

Jurnal Elektronik WACANA ETNIK - Vol 9 No 2, 2020, (102 - 115) p ISSN 2089-8746, e ISSN 2302-7142 
Tampang dilakukan empat kali dalam satu tahun, setiap kali pelaksanaannya itu selama sepuluh hari. Ada beberapa dari jamaah yang tidak sanggup untuk melanjutkan ibadah suluknya, karena banyaknya dosa-dosa yang dilihat. Setelah melihat dosa-dosa tersebut manusia akan sadar bahwa hidup di dunia ini tidak kekal, masih ada kehidupan yang hakiki yaitu alam akhirat. Meskipun banyak yang mengatakan ibadah suluk ini sudah kuno dan ketinggalan zaman, tetapi masyarakat tetap mempercayai cerita ini.

\section{Legenda Perseorangan}

Cerita tentang Harimau Penjaga Mudik Tampang ini tergolong ke dalam jenis legenda perseorangan (personal legends) karena menceritakan tokoh-tokoh tertentu yang dianggap oleh yang empunya benar-benar pernah terjadi. Cerita ini sampai sekarang masih dipercayai oleh masyarakat setempat. Salah satu bukti yang membuat masyarakat percaya akan cerita tersebut yaitu, sampai saat sekarang ini Harimau Penjaga Mudik Tampang masih ada, bertugas menjaga keseimbangan hidup manusia dan pembawa berita. Jika akan datang bencana di Mudik Tampang, Harimau Penjaga terlebih dahulu memberi tahu masyarakat pertanda, berupa auman dan menampakkan wujudnya kepada salah seorang manusia. Telah banyak masyarakat Mudik Tampang yang melihat Harimau Penjaga, baik disengaja atau pun tidak.

Mudik Tampang dikenal dengan Serambi Makkah Kecil di Tanah Rao, banyak terdapat orang-orang saleh. Banyak dari masyarakat Mudik Tampang mengatakan bahwa Harimau Penjaga merupakan wali Syekh Mudik Tampang terdahulunya. Dahulu di Mudik Tampang pernah terjadi musim kemarau, harimau menyampaikan berita tersebut kepada Syekh Bercukur Sebelah. Berita tersebut di sampaikan kepada seluruh masyarakat Mudik Tampang oleh Syekh. Sehingga seluruh masyarakat bersiap siap untuk menghadapi kemarau panjang tersebut, dengan mengumpulkan persediaan bahan makanan dan cadangan air minum. Ketika musim kemarau panjang datang, seluruh masyarakat Mudik Tampang selamat dari kelaparan dan kehausan.

Harimau Penjaga Mudik Tampang selalu memberi kabar pasti dan benar. Pada saat sekarang pun masyarakat percaya dengan keberadaan dan kabar yang di bawa oleh Harimau Penjaga. Cerita Harimau Penjaga Mudik Tampang sampai saat sekarang ini masih tetap dituturkan oleh empunya cerita. Dari hasil wawancara penulis dengan beberapa informan membenarkan adanya Harimau Penjaga Mudik Tampang ini. Pada saat sekarang ini, Harimau Penjaga tinggal di dalam hutan.

Cerita tentang Harimau Penjaga Mudik Tampang merupakan sebuah cerita yang mengisahkan Harimau yang hidup dengan nyaman dan tenteram di dalam hutan. Seiring dengan berjalannya waktu, hutan tempat tinggal harimau diterangi oleh manusia untuk dijadikan lokasi perkampungan, sontak memicu kemarahan Harimau. Menurut cerita Harimau menemui manusia-manusia yang sedang menerangi hutan tempat tinggalnya. Berniat untuk memakan satu persatu manusia yang telah merusak tempat tinggalnya. Namun hal itu tidak terjadi karena salah seorang manusia meminta maaf atas apa yang telah mereka perbuat. Akhirnya Harimau memaafkan kesalahan manusia dengan syarat Harimau tersebutlah yang akan menjadi penjaga kampung yang akan di buka. Pada umumnya masyarakat Mudik Tampang percaya dengan kebenaran cerita ini, hal ini dapat di buktikan dengan adanya perkampungan Mudik Tampang, Harimau sebagai penjaga ketenteraman dan keamanan kampung.

Jurnal Elektronik WACANA ETNIK - Vol 9 No 2, 2020, (102 - 115) p ISSN 2089-8746, e ISSN 2302-7142 
Dahulu Harimau Penjaga tinggal di kolong rumah warga, sekarang Harimau tinggal di dalam hutan. Cerita ini diakui kebenarannya oleh masyarakat Mudik Tampang, dari dahulu sampai saat sekarang ini Harimau Penjaga Mudik Tampang tetap dua ekor. Konon Harimau penjaga ini tidak dapat berkembang biak, Harimau Penjaga berbeda dengan Harimau pada umumnya, yaitu pada bagian kakinya tidak sama besar, kecil sebelah. Masyarakat percaya bahwa Harimau Penjaga ini adalah utusan dari rasul untuk menjaga alam Mudik Tampang. Cerita Harimau Penjaga masih tetap di tuturkan oleh beberapa orang di Mudik Tampang. Gelar Harimau Penjaga diperoleh dari julukan masyarakat terdahulunya.

Cerita tentang Kolong Wewe merupakan sebuah cerita yang tergolong ke dalam jenis legenda perseorangan (personal legends) karena cerita ini menceritakan tokoh-tokoh tertentu yang dianggap oleh empunya benar-benar pernah terjadi. Tokoh kolong wewe ini dianggap jahat, suka mencuri anak-anak kecil yang keluyuran malam. Konon tempat bermain Kolong Wewe ini dahulunya sampai sekarang berada di bawah pohon Beringin besar di dekat Surau Tuanku Mudik tampang. Masyarakat percaya bahwa Kolong Wewe bermain di bawah pohon beringin dekat Surau Tuanku Mudik Tampang pada jam 6 sore sampai jam 12 malam. Masyarakat setempat sering menggunakan legenda ini untuk mendidik anak-anaknya. Dalam isi teks cerita mengisahkan anak-anak yang sedang pulang mengaji dari Surau Tuanku Mudik Tampang tiba-tiba ditangkap oleh Kolong Wewe karena buang air kecil di bawah pohon beringin tempat Kolong Wewe bermain, sang anak di curi dan di bawa ke rumah Kolong Wewe untuk bermain dengan anaknya. Konon banyak yang berkata bila seorang anak sudah dicuri oleh Kolong Wewe maka tidak akan bisa kembali lagi ke rumahnya, anak yang telah dicuri akan hidup bersama dengan keluarga Kolong Wewe. Cerita ini dipercaya oleh masyarakat setempat sampai saat sekarang ini.

Legenda ini sampai saat sekarang ini masih tetap dituturkan bagi para orang tua yang memiliki anak-anak kecil yang berumur 5-8 tahun. Hal ini dilakukan agar anak-anak terbiasa untuk selalu pulang bermain tepat waktu. cerita ini juga bertujuan untuk menjadikan anak-anak berperilaku baik dan tidak suka keluyuran malam. Masyarakat Mudik Tampang pada saat sekarang ini masih menggunakan legenda Kolong Wewe untuk menghimbau anak-anaknya untuk segera pulang ke rumah karena hari sudah mulai malam.

Cerita tentang Makam Tampang juga tergolong ke dalam jenis legenda perseorangan (personal legends). Tokoh di dalam legenda ini adalah seseorang yang angkuh dan sombong menganggap dirinya paling hebat. Masyarakat percaya dengan legenda ini, salah satu bukti yang membuat masyarakat setempat percaya akan cerita tersebut yaitu, makam yang diceritakan dalam legenda masih ada. Makam ini terletak di dekat Surau Tuanku Mudik Tampang. Menurut masyarakat setempat, makam ini adalah makam Syekh Bercukur Sebelah, yaitu Syekh pertama yang ada di Mudik Tampang. Makam ini dipercaya memiliki keajaiban oleh masyarakat setempat, salah satu keajaiban yang dipercaya masyarakat yaitu, makam akan berguncang ketika makam tersebut ditimpa oleh batang kayu yang tumbang karena posisi makam berdekatan dengan pepohonan. Keajaiban lainnya yaitu, di dalam makam pernah terdengar suara orang azan. Makam ini dapat membuat seseorang merasa sakit, gatal-gatal, tidak enak badah, bahkan meninggal karena keramatnya. Hal tersebut terjadi apabila manusia tidak memiliki adab dan tata krama saat memasuki makam tersebut.

Jurnal Elektronik WACANA ETNIK - Vol 9 No 2, 2020, (102 - 115) p ISSN 2089-8746, e ISSN 2302-7142 
Masyarakat Mudik Tampang percaya akan cerita yang ada meskipun keajaiban dari makam tersebut sudah hilang atau sudah tidak ada lagi. Sebelum melaksanakan ibadah suluk, para jamaah suluk terlebih dahulu melakukan ziarah kubur ke makam Syekh Bercukur Sebelah barulah melaksanakan ibadah suluk. Pada saat memasuki bulan suci Ramadan, banyak orang yang berdatangan ke makam ini dan juga sebelum hari raya Idul Fitri. Sampai saat ini keajaiban makam yang masih ada yaitu, bisa membuat seseorang kesurupan apabila memiliki niat yang buruk terhadap seseorang atau pun orang banyak. Hal inilah yang membuat penulis mengklasifikasikan cerita rakyat ini ke dalam jenis legenda perseorangan (personal legends).

Cerita tentang Orang Bernazar sampai sekarang masih dipercayai oleh masyarakat setempat. Cerita ini merupakan sebuah cerita yang mengisahkan sepasang suami istri yang saleh yang belum dikaruniai anak. Menurut cerita, yang bernazar itu adalah istrinya. Sang istri sangat menginginkan anak perempuan, sudah bertiga anaknya semuanya laki-laki sehingga sang istri ingin memiliki anak lagi. Suatu hari sang istri bernazar untuk mendapatkan anak perempuan, "Jika saya mendapatkan anak perempuan saya akan menyembelih kambing untuk penduduk desa." Hari berganti minggu, minggu berganti bulan tibalah hari sang istri akan melahirkan. Semua masyarakat menanti kelahiran sang bayi dan pada akhirnya bayi yang keluar berjenis kelamin perempuan. Semua orang bergembira menyambut kelahiran bayi tersebut, apalagi sang istri bahagianya di atas bahagia. Karena bahagianya sang istri mendapat anak perempuan, dia lupa dengan nazarnya tersebut dan mengakibatkan kelamin anaknya berubah menjadi laki-laki.

Masyarakat Mudik Tampang pada umumnya percaya akan cerita ini, karena ada bukti yang sesuai dengan isi cerita tersebut. Salah satu bukti yang membuat masyarakat percaya akan cerita yaitu, masih hidupnya sang bayi yang bertukar jenis kelaminnya, beliau adalah keturunan Syekh Mudik Tampang yang ke-VIII. Setelah berumah tangga selama 12 tahun sang anak yang bertukar jenis kelaminya tidak memiliki keturunan, masyarakat percaya bahwa sang Tuanku Mudik Tampang tidak memiliki anak disebabkan bertukarnya jenis kelamin beliau pada saat bayi. Cerita ini tidak lagi di tuturkan karena cerita ini merupakan aib keluarga keturunan Syekh Mudik Tampang, apalagi beliau orang yang sangat di segani dan di hormati. Cerita ini tetap ada di pikiran masyarakat Mudik Tampang. Hal ini yang menjadi bukti bahwa cerita Orang Bernazar pernah benar-benar terjadi.

Cerita tentang Tonggak Bertuah menceritakan proses pembuatan Surau Lama. Masyarakat bergotong-royong mencari kayu ke dalam hutan belantara. Lokasi mencari kayu yang sangat jauh dari pemukiman masyarakat memaksa para pencari kayu bermalam di dalam hutan daripada pulang karena hari sudah mulai gelap. Kayu pembuat Surau Lamo di pilih yang terbaik. Dalam pembuatan surau masyarakat tidak menggunakan paku, tetapi hanya menghubungkan sisi-sisi kayu. Sebelum dibangun Surau Lamo seorang Syekh Mudik Tampang mendoakan kayukayu tersebut dan mendoakan keselamatan para pekerja. Cerita ini tergolong ke dalam jenis legenda perseorangan (personal legends) karena legenda ini menceritakan tentang tokoh-tokoh tertentu yang dianggap oleh empunya cerita pernah benar-benar terjadi. Masyarakat Mudik Tampang pada umumnya percaya akan cerita tersebut serta menganggap cerita ini benar-benar pernah terjadi pada masa dahulu. Salah-satu bukti yang membuat masyarakat setempat percaya akan cerita tersebut yaitu, terdapatnya bekas-bekas Surau Lamo di Mudik Tampang, serta masih

Jurnal Elektronik WACANA ETNIK - Vol 9 No 2, 2020, (102 - 115) p ISSN 2089-8746, e ISSN 2302-7142 
adanya Tonggak Bertuah yang masih bisa di lihat pada saat sekarang ini. Meskipun Surau Lamo sudah runtuh dan tinggal puing-puingnya saja masyarakat tetap mempercayai cerita ini.

Menurut penerus kepemimpinan Surau Tuanku Mudik Tampang yang ke-VIII keajaiban yang dimiliki oleh Tonggak Bertuah masih tetap ada sampai saat sekarang ini. Apabila ada yang bicara yang jelek di dekat Tonggak Bertuah mulut akan terasa gatal-gatal, demam, bahkan jika sudah berlebihan sekali dapat menyebabkan kesurupan. Penangkal dari itu semua ada, dengan cara meminta bantuan kepada Tongku Mudik Tampang. Surau Lamo beberapa saat yang lalu sudah runtuh di makan usia sehingga hanya menyisakan Tonggak Bertuah saja. Akan tetapi, seluruh bagunan Surau Lamo runtuh, lapuk, di makan rayap namun Tonggak Bertuah tetap kokoh dan tidak sedikit pun yang rusak. Surau Lamo berdekatan dengan lokasi Surau Tuanku Mudik Tampang. Hal ini yang membuat masyarakat percaya dengan cerita ini, masyarakat dapat melihat langsung bukti keberadaan Tonggak Bertuah tidak hanya mendengar ceritanya saja. Pada saat sekarang ini Tonggak Bertuah diletakkan di loteng Surau Tuanku Mudik Tampang agar tidak bisa tersentuh oleh siapa pun, karena bila sudah tersentuh Tonggak Bertuah dapat menyebabkan gatal pada kulit, demam, dan kesurupan.

\section{Legenda Keagamaan}

Cerita tentang Asal Syekh Mudik Tampang ini menceritakan perjalanan hidup Syekh Bercukur Sebelah dalam menyebar luaskan agama Islam. Syekh Bercukur Sebelah merupakan ulama besar, lulusan Mekah sehingga membuat beliau ahli dalam ilmu bahasa arab, mantiq dan ma'ani. Setelah lulus sekolah beliau menerapkan ilmu yang diperoleh ke wilayah Rao dan bagian Sumatera Utara. Masa muda Syekh dihabiskan di negeri orang untuk mengislamkan orang-orang dan berdakwah. Penulis mengklasifikasikan cerita ini ke dalam legenda keagamaan (religious legends) karena cerita ini erat kaitannya dengan orang-orang suci. Masyarakat percaya akan kebenaran cerita tersebut.

Legenda Keagamaan Gembok Syekh ini merupakan legenda tentang gembok yang terbuat dari emas murni yang digunakan untuk menggembok rumah Syekh di saat Syekh pergi berdakwah atau menjadi seorang musafir. Konon gembok tersebut sudah didoakan oleh Syekh sehingga tidak ada yang bisa membuka gembok Syekh selain dirinya. Banyak orang yang berniat mencuri gembok Syekh tersebut. Sampai sekarang gembok milik Syekh Mudik Tampang masih ada, di simpan oleh pewaris keturunan Tuanku Mudik Tampang yang ke VIII. Pada saat sekarang ini hanya tinggal gembok tanpa anak kunci, konon anak kunci tersebut tersimpan di dalam makam Syekh Mudik Tampang. Masyarakat setempat percaya bahwa kunci gembok tersebut itu tidak terbawa ke dalam makam Syekh melainkan dititipkan kepada orang kepercayaan Syekh. Bukti lain yang sangat akurat mengenai keberadaan Gembok Syekh ini adalah telah banyak orang-orang kaya dan peneliti yang ingin membeli gembok peninggalan Syekh Mudik Tampang ini. Oleh pewaris tidak dijual karena ini merupakan peninggalan masa lalu yang membuktikan adanya keajaiban yang dimiliki oleh orang suci Mudik Tampang yang bergelar Tuanku.

Tokoh di dalam cerita Harimau Penjaga Mudik Tampang adalah seorang Syekh yang saleh, menyiarkan agama Islam ke seluruh wilayah Rao dan bagian Sumatera Utara dengan berjalan kaki menjadi seorang musafir. Dalam setiap perjalanannya, Syekh selalu ditemani oleh Harimau Penjaga, konon Harimau-harimau ini berasal dari Mudik Tampang yang bertugas menjaga Syekh dalam berdakwah. Masyarakat percaya dengan legenda ini, salah satu bukti 
yang membuat masyarakat setempat percaya akan cerita tersebut yaitu, masih adanya Harimau Penjaga yang mengawal Syekh Mudik Tampang dalam berdakwah. Syekh yang sedang melakukan perjalanan jauh menuju tempat dakwahnya dibantu oleh Harimau agar cepat sampai ke tempat tujuan dengan cara ketika Syekh dalam keadaan tertidur Harimau menaikkan Syekh ke atas punggungnya.

Legenda Keris Syekh Bercukur Sebelah ini juga penulis golongkan ke dalam jenis legenda keagamaan (religious legends). Hal ini berdasarkan pada kenyataan bahwa terdapat hubungan yang kuat antara cerita ini dengan orang-orang suci. Cerita ini menceritakan tentang seorang Syekh yang membantu bencana banjir yang terjadi di dekat Surau Tuanku Mudik Tampang. Banjir terjadi akibat curah hujan yang tinggi ditambah dengan kecilnya tempat pembuangan air hujan, sehingga terjadilah banjir. Banyak masyarakat yang menderita berbagai macam penyakit, mulai dari gatal-gatal, sakit perut, demam berdarah, dan diare. Seluruh hasil pertanian penduduk gagal panen sehingga menyebabkan kelaparan.

Cerita ini juga mengisahkan sulitnya masyarakat Mudik Tampang mencari sumber air, disebabkan oleh musim kemarau. Sungai yang biasanya mengalir menjadi kering. Masyarakat kebingungan mencari sumber air, sehingga salah seorang warga desa di utus untuk menemui Syekh Bercukur Sebelah di Surau Tuanku Mudik Tampang untuk membantu bencana yang sedang dialami. Mendengar kabar tersebut membuat Syekh bergegas menuju lokasi kekeringan tersebut. Syekh mengumpulkan masyarakat di lapangan terbuka setelah berkumpul Syekh mengeluarkan keris miliknya dan menancapkannya ke tanah. Beberapa saat kemudian Syekh mencabut kerisnya dan kemudian keluarlah air dari bekas tancapan kerisnya.

Cerita tentang Makam ini mengisahkan seorang Syekh Bercukur Sebelah. Dahulu orang-orang Rao dan sekitar Pasaman Timur belajar agama kepada Syekh, hari-hari beliau dihabiskan untuk menyiarkan Agama Islam. Suatu hari Syekh jatuh sakit dan tidak lagi bisa mengajar orang-orang yang hendak memperdalam ilmu agama Islam. Hari terus berganti namun keadaan Syekh semakin memburuk dan akhirnya Syekh menghembuskan nafas terakhirnya pada hari Jumat. Konon masyarakat setempat percaya jika ada yang meninggal di hari Jumat akan masuk surga. Sampai saat sekarang ini pun masyarakat percaya bahwa apabila ada yang meninggal pada hari Jumat akan masuk surga. Masyarakat sekitar mempercayai bahwa hari Jumat itu adalah hari baik.

Pada umumnya masyarakat yang berada di Mudik Tampang percaya akan kebenaran cerita Makam Syekh ini. Hal ini dapat dilihat dari bukti adanya makam Syekh Bercukur Sebelah yang ada di Mudik Tampang di sekitar Surau Tuanku Mudik Tampang. Pada saat sekarang ini dapat kita lihat banyaknya orang-orang luar Tanah Rao yang berziarah ke makam Syekh. Mulai sejak Syekh di makamkan tidak henti-hentinya orang-orang meletakkan batu ke atas makam Syekh, meski pun begitu makam Syekh tidak pernah di penuhi oleh batu-batu yang di letakkan di atas pusaranyan. Hal ini lah yang menjadi bukti nyata keajaiban yang di miliki makam Syekh membuat semua masyarakat setempat percaya dengan cerita ini. Makam Syekh sudah berumur 330 tahun. Masyarakat menganggap Syekh adalah orang suci yang harus di contoh, meski pun beliau sudah tiada namun akhlak baik dan perjuagan beliau selalu dikenang masyarakat setempat sampai saat sekarang ini.

Legenda Naskah Kuno ini menceritakan Syekh Mudik Tampang yang menulis berbagai macam tulisan tangan bertemakan ajaran agama Islam, cerita nabi dan rasul, serta hadis. Konon tulisan-tulisan ini menjadi Naskah 
yang dapat dibaca dan menjadi bahan pengajaran. Dahulunya naskah-naskah yang ditulis oleh tangan Syekh Mudik Tampang ini memiliki kekuatan, seperti apabila seseorang dengan sengaja atau tidak membuka naskah-naskah yang telah Syekh tulis akan mengakibatkan bala kepada dirinya, orang tersebut akan merasa gatal-gatal pada bagian tangan yang telah menyentuh naskah, juga menyebabkan demam disebabkan oleh penunggu naskah yang merasa terganggu karena telah membuka tanpa izin. Masyarakat setempat percaya jika ingin membuka naskah-naskah yang telah ditulis Syekh ada adab dan tata karma yang harus di penuhi. Ada yang telah di langgar hanya dapat di obati oleh keturunan Syekh Mudik Tampang.

Penulis menanyai kepada Bapak Ahmad Khalidi Sanusi pewaris keturunan Tuanku Mudik Tampang yang ke VIIi mengenai kebenaran kekuatan gaib yang di miliki oleh naskah-naskah peninggalan Syekh, beliau membenarkan hal tersebut. Cerita ini sudah dibuktikan kebenarannya, masyarakat setempat juga mempercayai cerita Naskah Kuno ini, meski pun kekuatan naskah kuno ini tidak ada lagi bukan berarti masyarakat tidak mempercayai cerita ini dahulunya memang benar-benar pernah terjadi. Naskah-naskah peninggalan Syekh Bercukur Sebelah ini diletakkan di dalam lemari buku di Surau Tuanku Mudik Tampang. Beberapa tahun yang lalu sudah ada yang mencoba meneliti Naskah Kuno peninggalan Syekh Bercukur Sebelah ini, bahkan ada yang berniat untuk membeli naskah-naksah tersebut.

Cerita tentang Sorban milik Syekh ini menceritakan keajaiban yang dimiliki oleh sorban yang mampu menghilang ke mana saja yang kita inginkan. Meskipun dipakai setiap hari namun sorban tetap dalam keadaan wangi konon karena Syekh adalah yang suci. Dahulu Syekh sempat menghilang saat mengimami salat di Surau Tuanku Mudik Tampang, hal itu tidak sengaja terlihat oleh salah seorang makmumnya. Tidak lama kemudian Syekh kembali lagi memimpin salat. Banyak yang mengatakan sorban milik Syekh itu memiliki kekuatan, mampu membuat Syekh menghilang.

Pada umunya masyarakat yang berada di Mudik Tampang percaya akan kebenaran cerita Sorban Syekh ini. Hal ini dapat dilihat dari bukti-bukti yang telah di temui di Surau Tuanku Mudik Tampang, terdapatnya sorban Syekh Bercukur Sebelah yang mampu membuat dirinya menghilang. Sesuai dengan isi teks cerita sorban milik Syekh berwarna putih namun tidak wangi seperti dahulu. Meskipun keajaiban sorban milik Syekh Bercukur Sebelah telah tiada, tidak membuat kepercayaan masyarakat setempat hilang. Sorban milik Syekh sekarang ini di letakkan di dalam lemari. Di Mudik Tampang dari dahulunya sampai sekarang memang di kenal dengan orang-orang suci yang memiliki berbagai macam keajaiban. Meski pun pada saat sekarang tidak ada lagi yang memiliki keajaiban namun masyarakat setempat percaya dengan keajaiban-keajaiban yang pernah terjadi dahulunya. Semua peninggalan Syekh sudah di amankan oleh pewaris keturunan Syekh Mudik Tampang, baik itu Sorban, Gembok, Keris, Naskah Kuno, semua tersimpan dengan baik.

Cerita tentang Syekh Bercukur Sebelah ini tergolong ke dalam jenis legenda keagamaan (religious legends) karena, cerita ini menceritakan tentang orang-orang suci yang dianggap oleh yang empunya benar-benar pernah terjadi. Cerita ini sampai sekarang masih dipercayai oleh masyarakat setempat. Cerita ini merupakan sebuah cerita yang mengisahkan tentang seorang Syekh yang sangat saleh menghilang ke Kota Makah untuk membantu memadamkan kebakaran yang terjadi di sana. Pada saat Syekh menghilang ke Kota Makah Syekh dalam keadaan

Jurnal Elektronik WACANA ETNIK - Vol 9 No 2, 2020, (102 - 115) p ISSN 2089-8746, e ISSN 2302-7142 
memotong rambut. Pada umunya masyarakat setempat mengetahui legenda ini, bahkan cerita ini sudah tersebar di seluruh wilayah Pasaman. Hal ini yang membuat masyarakat setempat semakin mempercayai legenda ini.

Dahulu di Mudik Tampang memang orang-orang alim dan saleh memiliki keajaiban yang tidak dimiliki oleh orang biasanya. Orang-orang suci ini memiliki keajaiban atas ketakwaan dan ketaatannya menjalankan perintah Allah SWT. Di dalam hidupnya hanya Allah saja yang ia ingat. Cerita ini sampai saat sekarang ini masih tetap ada, namun tidak lagi dituturkan. Cerita tertinggal di dalam ingatan saja. Dengan canggihnya teknologi saat sekarang ini, membuat anak-anak tidak lagi berminat untuk mendengarkan legenda yang ada di kampung halamannya sendiri. Pada saat sekarang ini, kolam tempat Syekh menghilang dijadikan tempat menyembelih kambing atau biri-biri untuk membayar hutang nazar masyarakat setempat. Konon air di dalam kolam keramat mampu menyembuhkan berbagai macam penyakit. Banyak masyarakat setempat yang menggunakan air kolam untuk mandi, minum, dan kebutuhan hidup sehari-hari. Dari dahulu sampai sekarang air di dalam kolam keramat tidak pernah kering, meski pun sedang musim kemarau. Hal tersebutlah yang membuat masyarakat setempat mempercayai cerita orang suci Mudik Tampang Syekh Bercukur Sebelah.

TABEL 1. Klasifikasi Cerita prosa rakyat sekitar Surau Tuanku Mudik Tampang

\begin{tabular}{|c|c|c|}
\hline No & Cerita Rakyat & Klasifikasi Cerita \\
\hline 1. & Asal Nama Surau Tuanku Mudik Tampang & Legenda Setempat \\
\hline 2. & Asal Usul Nama Mudik Tampang 1 & Legenda Setempat \\
\hline 3. & Asal Usul Nama Mudik Tampang 2 & Legenda Setempat \\
\hline 4. & Asal Usul Nama Mudik Tampang 3 & Legenda Setempat \\
\hline 5. & Asal Usul Nama Mudik Tampang 4 & Legenda Setempat \\
\hline 6. & Penampakan Dosa & Legenda Alam Gaib \\
\hline 7. & Harimau Penjaga Mudik Tampang 1 & Legenda Perseorangan \\
\hline 8. & Harimau Penjaga Mudik Tampang 3 & Legenda Perseorangan \\
\hline 9. & Harimau Penjaga Mudik Tampang 4 & Legenda Perseorangan \\
\hline 10. & Kolong Wewe & Legenda Perseorangan \\
\hline 11. & Makam 2 & Legenda Perseorangan \\
\hline 12. & Orang Bernazar & Legenda Perseorangan \\
\hline 13. & Tonggak Bertuah & Legenda Perseorangan \\
\hline 14. & Asal Syekh Mudik Tampang & Legenda Keagamaan \\
\hline 15. & Gembok Syekh & Legenda Keagamaan \\
\hline 16. & Harimau Penjaga Mudik Tampang 2 & Legenda Keagamaan \\
\hline 17. & Keris Syekh Bercukur Sebelah 1 & Legenda Keagamaan \\
\hline 18. & Keris Syekh Bercukur Sebelah 2 & Legenda Keagamaan \\
\hline 19. & Makam 1 & Legenda Keagamaan \\
\hline 20. & Naskah Kuno & Legenda Keagamaan \\
\hline 21. & Sorban Syekh & Legenda Keagamaan \\
\hline 22. & Syekh Bercukur Sebelah & Legenda Keagamaan \\
\hline 23. & Tasbih Syekh & Legenda Keagamaan \\
\hline
\end{tabular}


Dari tabel di atas dapat dilihat bahwa ke dua puluh tiga cerita prosa rakyat yang berhasil didokumentasikan tersebut, semuanya tergolong ke dalam jenis legenda, yang terdiri dari lima legenda setempat (local legends), satu legenda alam gaib (supranatural legends), tujuh legenda perseorangan (personal legends), serta sepuluh legenda keagamaan (religious legends).

\section{PENUTUP}

Surau Tuanku Mudik Tampang merupakan warisan budaya yang penting. Peninggalan benda-benda peninggalan syekh Mudik Tampang dianggap mempunyai keramat dan menyimpan cerita. Syekh Mudik Tampang dikenal oleh masyarakat sekitar dengan keajaiban-keajaiban seperti dapat menghilang, membelah tanah menjadi dua, dan lainnya. Folklor lisan jenis cerita prosa rakyat sekitar Surau Tuanku Mudik Tampang merupakan sejarah yang sangat penting. Oleh karena itu, penelitian folklor di sekitar Surau Tuanku Mudik Tampang ini perlu dilakukan karena merupakan ciri khas dan identitas masyarakat yang mendiami wilayah tersebut.

\section{REFERENSI}

Azra, Azyumardi. 2003. Surau Pendidikan Islam dalam Transisi dan Modernisasi. Jakarta: Logos Wacana Ilmu. Danandjaja, James. 1991. Folklor Indonesia, Ilmu Gosip, Dongeng, Dan lain-lain. Jakarta: Grafiti.

Endraswara, Suwardi. 2009. Metode Penelitian Folklor. Yogyakarta: MedPress.

Endraswara, Suwardi. 2003. Metodologi Penelitian Sastra: Epistemologi, Mode, $\quad$ Teori, dan Aplikasi. Yogyakarta: Pustaka Widyatama.

Fitreni, Neti. 2015. "Ungkapan Larangan Rakyat di Kenagarian Lubuk Layang Kecamatan Rao Selatan Kabupaten Pasaman”. (skripsi). Padang: Universitas Negeri Padang.

Husnadi, Jupri dkk. 2014. http://juprihusnadi.blogspot.com/2014/12/tuanku-syekhrao.html?m=1. Diakses pada tanggal 28 Januari 2019, pada pukul $10.15 \mathrm{Wib}$.

Kato, Tsuyoshi. 2005. Adat Minangkabau dan Merantau: Dalam Perspektif Sejarah. Jakarta: Balai Pustaka.

Sudrya, Anita. 2012. "Dokumentasi dan Analisis Fungsi Cerita Rakyat dalam Masyarakat, Kecamatan Panti, Kabupaten Pasaman” (skripsi). Padang: Universitas Andalas. 